The University of Akron

\title{
IdeaExchange@UAkron
}

Proceedings from the Document Academy

University of Akron Press Managed

June 2017

\section{Nothing to Write Home About: Aphorisms Against Actuality}

Daniel Kissinger

kissid@uw.edu

Maisha Manson

mmanson@uw.edu

Please take a moment to share how this work helps you through this survey. Your feedback will be important as we plan further development of our repository.

Follow this and additional works at: https://ideaexchange.uakron.edu/docam

Part of the Inequality and Stratification Commons, Library and Information Science Commons, $\underline{\text { Politics and Social Change Commons, Regional Sociology Commons, and the Urban Studies and }}$ Planning Commons

\section{Recommended Citation}

Kissinger, Daniel and Manson, Maisha (2017) "Nothing to Write Home About: Aphorisms Against Actuality," Proceedings from the Document Academy: Vol. 4 : Iss. 1 , Article 17.

DOI: https://doi.org/10.35492/docam/4/1/17

Available at: https://ideaexchange.uakron.edu/docam/vol4/iss1/17

This Article is brought to you for free and open access by University of Akron Press Managed at IdeaExchange@UAkron, the institutional repository of The University of Akron in Akron, Ohio, USA. It has been accepted for inclusion in Proceedings from the Document Academy by an authorized administrator of

IdeaExchange@UAkron.For more information, please contact mjon@uakron.edu, uapress@uakron.edu. 


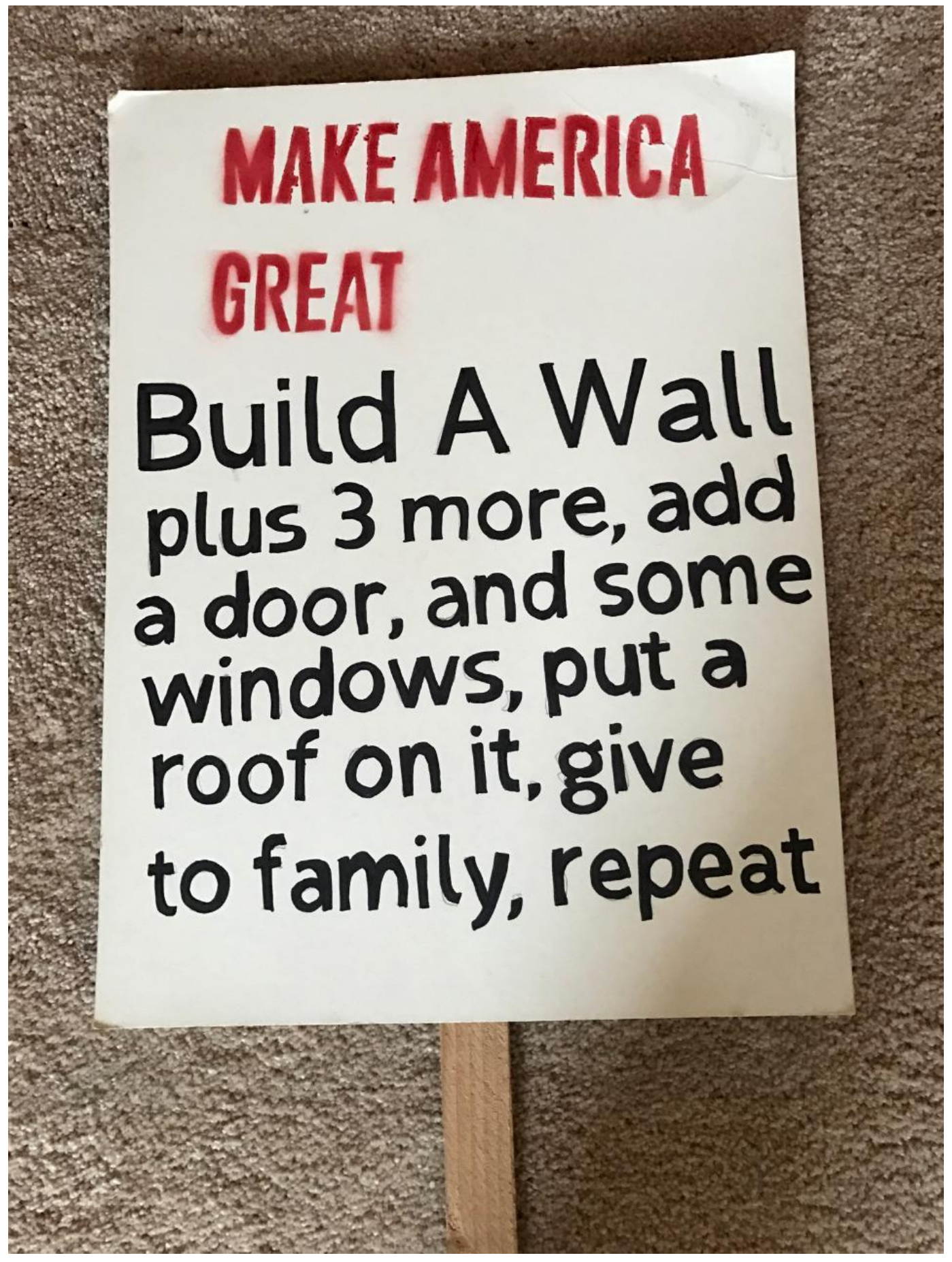


Welcome home. We write from Seattle, Washington.

We ask you to consider what that claiming of home-ness means. For you, for each of us, for our nation. We jump between many different documents and documentations of what it means to be, to make, to keep, to establish, to live at home. We look, particularly, to the aphorisms that collect around the sense and feeling of home, and home-ness. We posit counter-documents from historical archives to these structures of feeling which function to make (some of) us feel "at home," or at least a certain way, while pushing out those who are unwanted, who are unwelcome.

Through a mix of image and text, of aphorism and actuality we seek to displace the affective circuits through which "society" (White America) generates its discourses and imaginaries of home, of being home, of the home-land.

Much of this is imminently recognizable, is lived, has been lived, by people of color who have attempted (and/or succeeded) in making home in Seattle and the Pacific Northwest.

We open with an image of a protest sign, generated and created by another member of our graduate program in Cultural Studies. This sign, which was made for a solidarity protest of area high schoolers who staged school walk-outs in protest of the election of Donald Trump as President of the United States. The slogan references one of Donald Trump's campaign promises, one of his taglines, of "building a wall" between the United States and Mexico, in an attempt to stymie "illegal immigration" of "illegal aliens" into the United States by underpaid and exploited Mexican and Central and South American laborers. They are not welcome in the United States of America. They should just "go home."

Home is a point of disjuncture, of exclusion, through which the national imaginary is generated, reproduced, and protected. Who is allowed to "be at home," that is to feel safe, to be safe, to feel welcome, wanted, is always already a deadly political act.

For this brief engagement, we connect a small number of events and documents in the Puget Sound area to applicable aphorisms around the idea of home. Due to length this foray is fleeting and incomplete. We hope to offer insight into how this essay "aphorisms against actuality" could be teased out and mobilized in other contexts, other places, as a project to destabilize the sedimentation of sentiments and structures of feeling which authorize racialized and settler colonial histories and relations of power. 
The "events" which we highlight are: the theft of the Pacific Northwest from Indigenous peoples, situated at the 1855 Treaty of Point Elliott; the racialization of the demo-geography of Seattle through "Racial Covenants" as a legitimate legal apparatus of exclusion and the enforcement of generational poverty and exclusion; and the internment of Japanese and Japanese American people through Order 9066 and the theft and appropriation of their land.

\section{Welcome home.}

We write to not ignore that this is stolen, occupied indigenous land. In 1855, the Treaty of Point Elliott was signed, in 1859 it was ratified, the Duwamish people exchanging 54,000 acres of their land for certain rights and privileges that have long since gone unrecognized. In 1855 the Dwamish, Suquamish, Sk-kahl-mish, Sam-ahmish, Smalh-kamish, Skope-ahmish, St-kah-mish, Snoqualmoo, Skaiwha-mish, N'Quentl-ma-mish, Sk-tah-le-jum, Stoluck-wha-mish, Sno-ho-mish, Skagit, Kik-i-allus, Swin-a-mish, Squin-ah-mish, Sah-ku-mehu, Noo-wha-ha, Nook-wa-chah-mish, Mee-see-qua-guilch, Cho-bah-ah-bish, and other allied and subordinate tribes and bands were lied too. The Duwamish tribe, the traditional caretakers of this land, whose Chief Sealth (or Chief Sealth, Seathle, Seathl, or See-ahth), whose name white settlers took to name Seattle, is, as of 2016, still seeking federal recognition of their tribal sovereignty. At the time of writing the Duwamish still lack federal recognition, despite having it granted for a brief time in 2001 by the Clinton administration (a decision reversed immediately by the new Bush administration).

\section{Home sweet home.}

Between 1926 and 1968 if you weren't "quite right," that means if you weren't "quite white," weren't white, weren't the right type of white, you couldn't purchase or own a home in many neighborhoods of Seattle. In certain subdivisions within the Beacon Hill, Bitter Lake, Blue Ridge, Broadview, Bryant, Duwamish, Eastlake, Greenlake, Greenwood, Haller Lake, Hawthorne Hills, Lake City, Lakeridge, Laurelhurst, Maple Leaf, Matthews Beach, Montlake, Olympic Hills, Blue Ridge, North College Park, Northgate, Pinehurst, Queen Anne, Rainier Valley, Ravenna, Sandpoint, Victory Heights, View Ridge, Wedgewood, West Seattle, and Windermere neighborhood only people of white race and descent could own homes and property, not to mention the neighborhoods with specific prohibitions against people of black and African descent, of Asian descent, and against Jewish people. Despite being ruled unconstitutional in $\underline{1948}$, and 
unenforceable in 1968 through the Fair Housing Act these covenants were still being found a decade ago.

\section{Home is where the heart is.}

In 1942 the theft of land and internment of Japanese and Japanese-American people in the Seattle area is begun through Eisenhower's Executive Order 9066. Allowed to bring only what they could carry, the state begins the appropriation of Japanese American land. These people are sent to the "Camp Harmony" assembly camp in Puyallup - which was and continues to be the site of the Washington State Fair (formerly the Puyallup Fair), and who were then sent on to the internment camp in Minidoka, Idaho among others. Japanese and JapaneseAmerican land is stolen and put to use, one example being the Panama Hotel - a Japanese-built and -owned business which housed and houses the personal artifacts of those interned who were never allowed to return to their homes.

Other Seattle-specific areas in which this essay could easily be expanded could look at the homeless crisis in the city, specifically looking at the formations, regulations, dissolution, discussions of homeless encampments like The Jungle, and its successor The Triangle. Or, a look at (the lack of) affordable housing in Seattle, the development of "Amazonia," rising rent prices, and people who are resisting the gentrification of Seattle, the erosion of racialized neighborhoods with particular histories and character, and who are fighting for affordable housing in the area.

This is an enunciation of home, the ways in which home is stolen. Of how and where and why homes are made, how they're built. The ways in which homes are broken. The ways in which homeliness is denied. The ways in which homelessness are created, recreated, reproduced, circulated and brought about into this world.

Like place-specific examples and histories there are many other aphorisms, idioms, and phrases that could have been analyzed. We invite you to ruminate on these: a woman's place is in the home; bringing home the bacon; charity begins at home; eat(en) out of house and home; go hard or go home; home is where I lay my hat; home away from home; a man's home is his castle; men make houses, women make homes; there's no place like home; (the) home stretch. Can you think of others?

Let the protest sign we opened this essay with be a reminder, a house is not a home. But it's a necessary start. 